\title{
Cake or Cookies? Facing Business and Management Bilingual Studies
}

\author{
Javier de Esteban Curiel \\ Rey Juan Carlos University, Madrid, Spain \\ Jaime Alvarez Plaza \\ Complutense University, Madrid, Spain \\ Arta Antonovica \\ Rey Juan Carlos University, Madrid, Spain
}

\begin{abstract}
The main aim of this article is to approach the phenomena of collective bilingualism of the students of Business and Management studies in a non-speaking country (such as Spain), and their familiarity with English vocabulary in the subject content. From participial observation and experience of several years of the authors and professors' studies in bilingual programmes at university level, this research summarizes the most important pedagogical aspects of particular interest in this type of education, distinguishing group (cake) and individual (cookies) activities. This paper tries to reflect if the techniques employed by group (cake) or individual (cookies) teaching speed up the students to acquire enough skills to perform successfully academic activities, oral and written in the language of Shakespeare. As a metaphor, the authors have assimilated group activities (for instance, lecture hours) with a cake that is sharable, and individual activities (for instance, personal tutor sessions) with cookies that are not sharable.
\end{abstract}

Keywords: collective and individual bilingualism, bilingual education techniques, communication

\section{Introduction}

This article summarizes the research findings of a study with objectives focused on analyzing the acquired language skills of English of the students of the subject "Marketing Research" of a degree "Market Research Bilingual”, given at the University Rey Juan Carlos in Madrid, Campus of Vicálvaro, during the academic year 2009-2010. There also were involved students of the following programs_-"Principles of Business Financial Management”, "Financial Management”, “Accounting” and "Finance” of the Complutense University in Madrid of the bilingual degrees "Marketing Research", and "Business Administration" and "Economics" during the academic year 2010-2011.

Therefore, the use of English in non-language subjects as in this case, increases the contact time with the

Javier de Esteban Curiel, Professor, Department of Marketing, Rey Juan Carlos University.

Jaime Alvarez Plaza, Professor, Department of Finance, Complutense University.

Arta Antonovica, Department of Modern Language, Rey Juan Carlos University.

Correspondence concerning this article should be addressed to Javier de Esteban Curiel, Department of Marketing, Rey Juan Carlos University, Madrid 28032, Spain. E-mail: javier.deesteban@urjc.es. 
foreign language and at the same time opens other dimensions of it-like a specific vocabulary of the specialized and technical disciplines.

It is important to emphasize the exploratory nature of this study, due to the limitation of the used sample, thus constituting a first approach to the investigation and analysis in the field of competence of individual or collective bilingualism.

\section{What is Bilingualism?}

The authors of classical definition of bilingualism, Siguen and Mackey (1986, pp. 17-18), affirm that "the bilingual programs are taught in two languages, one of which usually is the students' native language”. In this sense, in the previous mentioned bilingual degrees, English and Spanish are used as vehicular languages of communication and instruction of the subjects. The use of English in real situations, such as problems solving or justification of individual opinions, gives authenticity and usefulness, thus allowing students more control over it (García, 2005) and to concentrate more on the transmission of information in the study of formal aspects (Cummins, 2002; Genesee, 1999).

On the other hand, for completing and giving more conceptual review of the classic definition of Siguan and Mackay, professor Moreno (2008, p. 207) also sets out the first known definitions of bilingualism, that are proposed by Lenonar Bloomfield (1933), Einar Haugen (1953), and Uriel Weinreich (1953). For the first author, bilingualism is "native domain of two languages"; Haugen wrote that the bilingualism "uses complete expressions and with the meaning in other languages"; and finally, for Weinreich bilingualism is "practice of two languages used alternatively".

Likewise and in relation to the theoretical framework of this article, Moreno (2008, p. 208) suggests that beyond the definitions, we can speak of two types of bilingualism: the individual bilingualism, which affects individuals intrinsically, and the collective bilingualism that affects communities and individuals as members of these communities. In paragraph of the methodology, we will develop this idea to provide the theoretical framework proposed in this research.

\section{The Market Research Degree in Bilingual and Subject “Marketing Research”}

Those bilingual programmes established by the Universidad Rey Juan Carlos and the Complutense University have developed an academic practice that can be referred as "late partial immersion", if we compare it with other university education in the rest of Europe. In fact, in other countries of our European context have been offering engineering programmes, degrees or diplomas completely in English language for a long time period (except of course the English-speaking countries: the United Kingdom and Ireland).

Respects to the subject of "Marketing Research", its contents are focused on the need of information for making marketing decision. As Malhorta (2004, p. 7) stated, it should be mentioned that this course is a systematic approach, what is needed for the planning of all phases of the process of "Marketing Research". Therefore, the procedures that are followed at each stage of the process are well-established, and as far as possible, are planned in advance.

In addition, the section of the English language and its "application" in the techniques of the subject will support the student to apply concepts and understandings from one context to a different one, for example, 
marketing and business strategies of various productive sectors worldwide. Likewise, some learning task must be performed based on the resolution of problems, with a business report written in English, and also an oral presentation in English. Thereby, it enables a student with some conceptual instruments and rules how to use "Marketing Research", and therefore it can be applied wherever and whenever. In the empiric application is perhaps where the older student will use the English language, student-centered, which is how it should be.

\section{Individual Bilingualism and Collective Bilingualism}

The theoretical analysis of this article is based on individual and collective bilingualism, previously introduced in the theoretical part of bilingualism, and in the basic model of communication (see Figure 1) as a general technique for learning, where are different interactions between emitter and receiver, being able to distinguish individual and collective interaction:

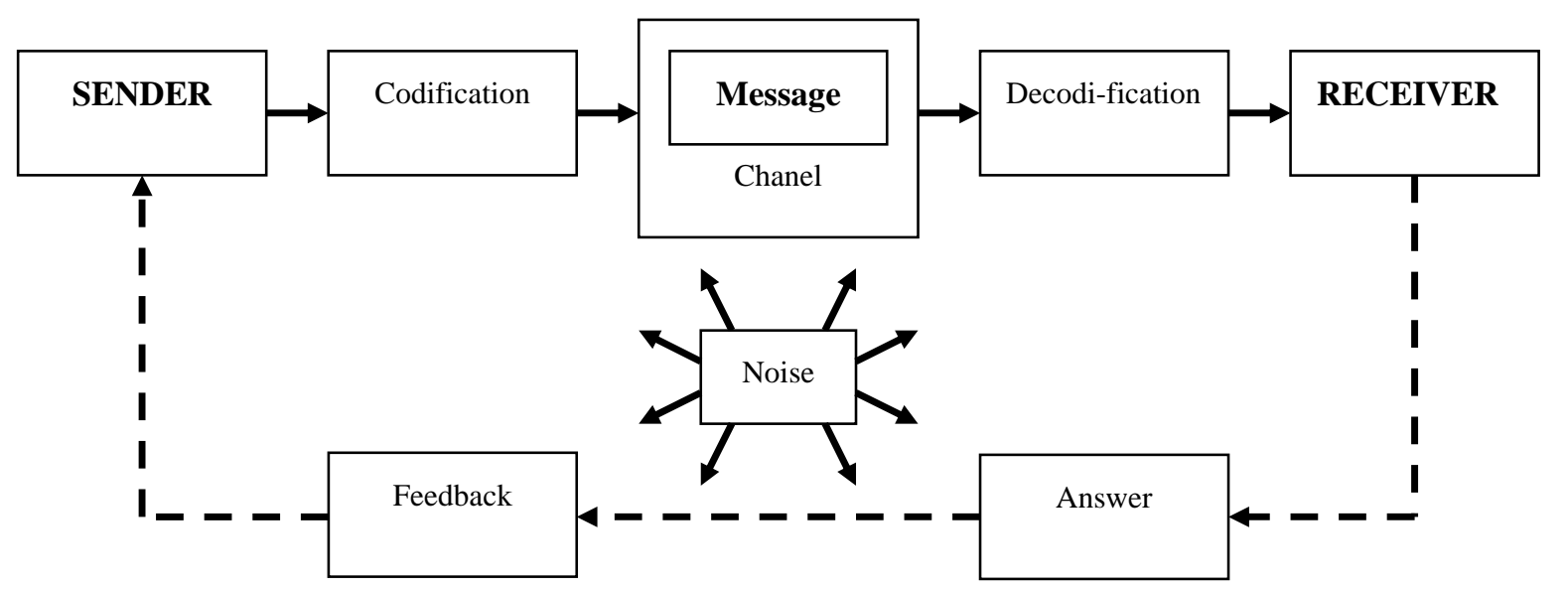

Figure 1. Basic model of communication. Source: The elaboration by Kotler and Lane (2006, p. 568).

(1) Individual interaction (two elements): one emitter and various receivers (for example: individual tutoring; student in front of a book, CD, DVD, and webpage in English...);

(2) Collective interaction (more than two elements): one emitter and various receivers (sample: master class); various emitters and one receiver (sample: oral group presentation to the teacher); various emitters and various receivers (sample: presentation of two teachers to several students).

In this way, based on formal or informal interactions and extrapolating interactions of university teaching techniques in bilingual programmes used by the authors of this article in their classes, it can be classified according to the same principles, depending on individual bilingualism and/or collective bilingualism.

Individual bilingualism techniques:

(1) Formal academic areas:

- Teacher-student (e.g., tutoring).

(2) Extra academic areas:

- Student-student (e.g., meeting outside of the class between two students);

- Student-hardware (e.g., book, CD, DVD, web page in English...).

Collective bilingualism techniques:

(1) Formal academic areas: 
- Teacher-students (e.g., teacher’s master class involving all the students);

- Teacher-students (e.g., group oral presentation to the teacher).

(2) Extra academic areas:

- Students (e.g., meeting outside of the class among more than two students);

- Students with native speakers (e.g., meeting outside of the class among students and native speakers in a bar).

In this sense, this classification of bilingualism techniques applied in the following subjects "Marketing Research”, “Principles of Business Financial Management”, “Financial Management”, “Accounting” and "Finance" have intended to fulfill the role of the both universities activities on the one hand (for example, the master class), and extra-academic activities on the other hand (for example, meeting of the students with native English-speakers in a bar).

\section{Methodology of This Research Study}

To achieve the objectives of this research study on bilingualism, it has been implemented a survey of 89 students of several bilingual bachelor degrees of business and management studies. In particular, 13 students enrolled in the subjects of "Marketing Research" in the Rey Juan Carlos University (Madrid, Spain); 18 students of "Principles of Business Financial Management”, 15 students of "Financial Management”, 20 students of "Accounting", and 23 students of "Finance" in the Complutense University (Madrid, Spain) of the bilingual degrees in "Marketing Research" and "Business Administration" and "Economics” respectively in the academic year 2010-2011. The questionnaire consists of nine questions, basically structured into closed questions to be answered by checking the appropriate box. In addition, there are some questions that ask for numerical information, and others score the importance of a particular bilingual technique using value-affirmations on a scale ranging from one-very low/low to five-very high/good.

The main completion time of the questionnaire is about six minutes, and basically is divided into two sections: (1) information on socio-demographic profile of students; and (2) on assessment of the different techniques of bilingual education (cake or cookies) used in and outside lecture hours.

The surveys were conducted in the last week of April 2010 at the Rey Juan Carlos University and in the last week of February 2011 at the Complutense University, where the questionnaires were handed out to students during a group tutorial session established for this purpose at each University. The questionnaires had been fully completed by all students, so no sampling was needed as all students were covered for the research. Thus, the data analysis has been performed through the software Statistical Package for Social Sciences (SPSS, version 15.0), using frequency analyses, crosstabs and correlations.

\section{Findings and Discussion}

This section presents the main findings obtained in the survey of 89 students of bilingual studies of the Rey Juan Carlos University and the Complutense University. Thus, the data analysis has been applied through univariant and bivariant statistical formulas.

The age for these bilingual students is predominantly towards a 24- and 25 -year-old profile, with $48.3 \%$ of this population, followed by students aged 26-27 years old with $28 \%$ of total students (see Table 1). 
Table 1

Age of Students

\begin{tabular}{llcccc}
\hline & Age of the students & Frequency & Percent (\%) & Valid percent (\%) & Cumulative percent (\%) \\
\hline \multirow{2}{*}{ Valid } & $18-23$ & 9 & 10.1 & 10.1 & 10.1 \\
& $24-25$ & 43 & 48.3 & 48.3 & 58.4 \\
& $26-27$ & 28 & 31.5 & 31.5 & 89.9 \\
More than 27 & 9 & 10.1 & 10.1 & 100.0 \\
& Total & 89 & 100.0 & 100.0 & \\
\hline
\end{tabular}

Note. Source: The authors' elaboration.

With regards to the nationality (see Table 2), most of the students are Spanish (95.5\%), then followed by Germans (2.2\%), Romanians and Dutch (both with 1.1\%).

Table 2

Nationality of Students

\begin{tabular}{llcccc}
\hline & Nationality & Frequency & Percent (\%) & Valid percent (\%) & Cumulative percent (\%) \\
\hline Valid & Spain & 85 & 95.5 & 95.5 & 95.5 \\
& Germany & 2 & 2.2 & 2.2 & 97.8 \\
& Romania & 1 & 1.1 & 1.1 & 98.9 \\
& Holland & 1 & 1.1 & 1.1 & 100.0 \\
& Total & 89 & 100.0 & 100.0 & \\
\hline
\end{tabular}

Note. Source: The authors' elaboration.

The Table 3 shows that the majority of the bilingual students are currently working (61.8\%) in different fields and positions, and $38.2 \%$ of them do not have a job. As we have mentioned earlier, the age ranges from 23 to 27 , so in accordance with the first steps of their labour life.

Table 3

Student's Working Position

\begin{tabular}{|c|c|c|c|c|c|}
\hline \multicolumn{6}{|c|}{ Are you working currently? } \\
\hline & & Frequency & Percent (\%) & Valid percent (\%) & Cumulative percent (\%) \\
\hline \multirow[t]{3}{*}{ Valid } & Yes & 55 & 61.8 & 61.8 & 61.8 \\
\hline & No & 34 & 38.2 & 38.2 & 100.0 \\
\hline & Total & 89 & 100.0 & 100.0 & \\
\hline
\end{tabular}

Note. Source: The authors' elaboration.

Table 4

Previous Experience in Bilingual Studies

\begin{tabular}{|c|c|c|c|c|c|}
\hline \multicolumn{6}{|c|}{ Did you have previous experience in bilingual studies? } \\
\hline & & Frequency & Percent (\%) & Valid percent (\%) & Cumulative percent (\%) \\
\hline \multirow[t]{3}{*}{ Valid } & Yes & 5 & 5.6 & 5.6 & 5.6 \\
\hline & No & 84 & 94.4 & 94.4 & 100.0 \\
\hline & Total & 89 & 100.0 & 100.0 & \\
\hline
\end{tabular}

Note. Source: The authors' elaboration.

Just 5.6\% of students have previous experience in bilingual studies, certainly in high school before they got their university degrees.

Analysing the information regarding the number of times that these students have been in an 
English-speaking country more than one month, it can be commented that basically the respondents have never been in English-speaking countries over one month (see Table 5).

Table 5

Stay in English-Speaking Countries

\begin{tabular}{|c|c|c|c|c|c|}
\hline \multicolumn{6}{|c|}{ How many times have you been in an English-speaking country more than one month? } \\
\hline & & Frequency & Percent (\%) & Valid percent (\%) & Cumulative percent (\%) \\
\hline \multirow[t]{5}{*}{ Valid } & Never & 38 & 42.7 & 42.7 & 42.7 \\
\hline & Once & 32 & 36.0 & 36.0 & 78.7 \\
\hline & Twice & 12 & 13.5 & 13.5 & 92.1 \\
\hline & More than two times & 7 & 7.9 & 7.9 & 100.0 \\
\hline & Total & 89 & 100.0 & 100.0 & \\
\hline
\end{tabular}

Note. Source: The authors' elaboration.

In this sense and based upon previous table, $84.3 \%$ of these bilingual students do not have any official accreditation confirming their knowledge of English language (see Table 6). Only 15.7\% have passed an exam as TOEFL, Cambridge Certificate, etc., proving an acceptable level of English language.

Table 6

Official Accreditation of Knowledge of English

\begin{tabular}{|c|c|c|c|c|c|}
\hline \multicolumn{6}{|c|}{ Do you have any official accreditation of your knowledge of English language (e.g., TOEFL, Cambridge Certificate, etc.)? } \\
\hline & & Frequency & Percent (\%) & Valid percent (\%) & Cumulative percent (\%) \\
\hline \multirow[t]{3}{*}{ Valid } & Yes & 14 & 15.7 & 15.7 & 15.7 \\
\hline & No & 75 & 84.3 & 84.3 & 100.0 \\
\hline & Total & 89 & 100.0 & 100.0 & \\
\hline
\end{tabular}

Note. Source: The authors' elaboration.

Table 7 expresses the level of English language considered by the students at the beginning and mid-term of the course. In a scale of 1 -very poor out 5 -excellent, nearly $60 \%$ have scored 3 at the beginning (medium level) and near three quarter (73\%) have scored 4 at the mid-term course, showing a progress along the year.

Table 7

Consideration of Their Level of English at the Beginning and at The Mid-term of the Course

\begin{tabular}{|c|c|c|c|c|c|}
\hline \multicolumn{6}{|c|}{ How does your level of English at the beginning of the academic year 2010-2011? } \\
\hline & & Frequency & Percent (\%) & Valid percent (\%) & Cumulative percent (\%) \\
\hline \multirow[t]{4}{*}{ Valid } & 2 & 5 & 5.6 & 5.6 & 5.6 \\
\hline & 3 & 53 & 59.6 & 59.6 & 65.2 \\
\hline & 4 & 31 & 34.8 & 34.8 & 100.0 \\
\hline & Total & 89 & 100.0 & 100.0 & \\
\hline \multicolumn{6}{|c|}{ How does your level of English at the midterm of the academic year 2009-2010? } \\
\hline & & Frequency & Percent (\%) & Valid percent (\%) & Cumulative percent (\%) \\
\hline \multirow[t]{4}{*}{ Valid } & 3 & 2 & 2.2 & 2.2 & 2.2 \\
\hline & 4 & 65 & 73.0 & 73.0 & 75.3 \\
\hline & Excellent & 22 & 24.7 & 24.7 & 100.0 \\
\hline & Total & 89 & 100.0 & 100.0 & \\
\hline
\end{tabular}

Note. Source: The authors' elaboration. 
The last question of the survey is to look for the perception of the students (scale 1-very bad out 5-very good) regarding the different techniques applied or recommended by the teachers during their lectures or student's free time and leisure. Hence, the first three techniques correspond to individual bilingualism techniques and the next four belong to collective bilingualism techniques (see Table 8).

Table 8

Scores Assigned by the Students to the Different Techniques Applied or Recommended by the Teachers During Their Lectures or Students Free-Time and Leisure

\begin{tabular}{|c|c|c|c|c|c|}
\hline \multicolumn{6}{|c|}{ Individual tutorial hour } \\
\hline & & Frequency & Percent (\%) & Valid percent (\%) & Cumulative percent (\%) \\
\hline \multirow[t]{4}{*}{ Valid } & 2 & 6 & 6.7 & 6.7 & 6.7 \\
\hline & 3 & 39 & 43.8 & 43.8 & 50.6 \\
\hline & 4 & 44 & 49.4 & 49.4 & 100.0 \\
\hline & Total & 89 & 100.0 & 100.0 & \\
\hline \multicolumn{6}{|c|}{ Meeting outside of class between two students } \\
\hline & & Frequency & Percent (\%) & Valid percent (\%) & Cumulative percent (\%) \\
\hline \multirow[t]{3}{*}{ Valid } & 1 & 12 & 13.5 & 13.5 & 13.5 \\
\hline & 2 & 77 & 86.5 & 86.5 & 100.0 \\
\hline & Total & 89 & 100.0 & 100.0 & \\
\hline \multicolumn{6}{|c|}{ 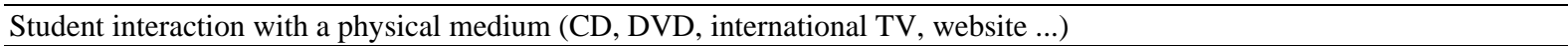 } \\
\hline & & Frequency & Percent (\%) & Valid percent $(\%)$ & Cumulative percent (\%) \\
\hline \multirow[t]{4}{*}{ Valid } & 3 & 15 & 16.9 & 16.9 & 16.9 \\
\hline & 4 & 54 & 60.7 & 60.7 & 77.5 \\
\hline & 5 & 20 & 22.5 & 22.5 & 100.0 \\
\hline & Total & 89 & 100.0 & 100.0 & \\
\hline \multicolumn{6}{|c|}{ Lecture by professor involving all students } \\
\hline & & Frequency & Percent (\%) & Valid percent (\%) & Cumulative percent (\%) \\
\hline \multirow[t]{4}{*}{ Valid } & 3 & 7 & 7.9 & 7.9 & 7.9 \\
\hline & 4 & 62 & 69.7 & 69.7 & 77.5 \\
\hline & 5 & 20 & 22.5 & 22.5 & 100.0 \\
\hline & Total & 89 & 100.0 & 100.0 & \\
\hline \multicolumn{6}{|c|}{ Oral group presentation } \\
\hline & & Frequency & Percent (\%) & Valid percent (\%) & Cumulative percent (\%) \\
\hline \multirow[t]{5}{*}{ Valid } & 2 & 6 & 6.7 & 6.7 & 6.7 \\
\hline & 3 & 20 & 22.5 & 22.5 & 29.2 \\
\hline & 4 & 49 & 55.1 & 55.1 & 84.3 \\
\hline & 5 & 14 & 15.7 & 15.7 & 100.0 \\
\hline & Total & 89 & 100.0 & 100.0 & \\
\hline \multicolumn{6}{|c|}{ Meeting outside of class among more than two students } \\
\hline & & Frequency & Percent (\%) & Valid percent (\%) & Cumulative percent (\%) \\
\hline \multirow[t]{4}{*}{ Valid } & 1 & 18 & 20.2 & 20.2 & 20.2 \\
\hline & 2 & 58 & 65.2 & 65.2 & 85.4 \\
\hline & 3 & 13 & 14.6 & 14.6 & 100.0 \\
\hline & Total & 89 & 100.0 & 100.0 & \\
\hline \multicolumn{6}{|c|}{ Students meeting with natives in a bar, cafeteria, etc. } \\
\hline & & Frequency & Percent (\%) & Valid percent (\%) & Cumulative percent (\%) \\
\hline \multirow[t]{4}{*}{ Valid } & 3 & 11 & 12.4 & 12.4 & 12.4 \\
\hline & 4 & 36 & 40.4 & 40.4 & 52.8 \\
\hline & 5 & 42 & 47.2 & 47.2 & 100.0 \\
\hline & Total & 89 & 100.0 & 100.0 & \\
\hline
\end{tabular}

Note. Source: The authors' elaboration. 
Those results indicate that the students have a great interest in meetings with natives in a bar, cafeteria in order to improve their English (higher percentage of highest value: 47.2\% students scored 5). On the other hand, the worst technique according to the students is when they have meetings outside of the class among more than two students (higher percentage of lowest value: $20.2 \%$ students scored 1).

Taking into consideration the means of the scores for each technique applied or recommended by the teachers during their lectures or student's free time and leisure (see Table 9), most of them are well considered (more than 3 as mean value), except for meetings outside of the class between two students, and meetings outside of the class among more than two students (1.87 and 1.94 respectively as means). Whereas, the most preferred technique is without doubt when they gather with natives outside the university, in a bar or cafeteria (the mean is 4.35).

Table 9

Statistic Means of the Different Bilingual Techniques

\begin{tabular}{|c|c|c|c|c|c|c|c|c|}
\hline \multicolumn{9}{|c|}{ Statistic mean of each bilingual technique } \\
\hline & & $\begin{array}{l}\text { Individual } \\
\text { tutorial hours }\end{array}$ & $\begin{array}{l}\text { Meeting } \\
\text { outside of } \\
\text { class between } \\
\text { two students }\end{array}$ & $\begin{array}{l}\text { Student interaction } \\
\text { with a physical } \\
\text { medium (CD, DVD, } \\
\text { international TV, } \\
\text { website ...) }\end{array}$ & $\begin{array}{l}\text { Lecture by } \\
\text { Professor } \\
\text { involving all } \\
\text { students }\end{array}$ & $\begin{array}{l}\text { Oral group } \\
\text { presentation }\end{array}$ & $\begin{array}{l}\text { Meeting } \\
\text { outside of class } \\
\text { among more } \\
\text { than two } \\
\text { students } \\
\end{array}$ & $\begin{array}{l}\text { Students } \\
\text { meeting with } \\
\text { natives in a bar, } \\
\text { cafeteria, etc. }\end{array}$ \\
\hline \multirow{3}{*}{$\mathrm{N}$} & Valid & 89 & 89 & 89 & 89 & 89 & 89 & 89 \\
\hline & Missing & 0 & 0 & 0 & 0 & 0 & 0 & 0 \\
\hline & Mean & 3.43 & 1.87 & 4.06 & 4.15 & 3.80 & 1.94 & 4.35 \\
\hline
\end{tabular}

Note. Source: The authors' elaboration.

Finally, based on the statistical analysis of correlations among the factors studied in this research, Table 10 establishes that it exists a slight correlation between the variable "are you working” vis a vis "meeting outside of class among more than two students" (0.508 as Pearson coefficient); and between "student interaction with a physical medium (CD, DVD, international TV, website ...)” and "lecture by professor involving all students" (0.585 as Pearson coefficient). Consequently, the students that interact with computers to improve their English language also appreciate the traditional lectures where professors involve all students for the development of the class.

Table 10

Statistic Correlations of the Different Variables Studied in This Research

\begin{tabular}{|c|c|c|c|c|c|}
\hline \multicolumn{6}{|l|}{ Correlation } \\
\hline & & $\begin{array}{l}\text { Are you } \\
\text { working } \\
\text { currently? }\end{array}$ & $\begin{array}{l}\text { Student interaction } \\
\text { with a physical } \\
\text { medium (CD, DVD, } \\
\text { international TV, } \\
\text { website ...) }\end{array}$ & $\begin{array}{l}\text { Lecture by } \\
\text { professor } \\
\text { involving all } \\
\text { students }\end{array}$ & $\begin{array}{l}\text { Meeting outside of } \\
\text { class among more } \\
\text { than two students }\end{array}$ \\
\hline \multirow{3}{*}{$\begin{array}{l}\text { Are you working } \\
\text { currently? }\end{array}$} & Pearson correlation & 1.000 & -0.071 & $0.393^{* *}$ & $0.508^{* *}$ \\
\hline & Sig. (2-tailed) & & 0.510 & 0.000 & 0.000 \\
\hline & $\mathrm{N}$ & 89 & 89 & 89 & 89 \\
\hline \multirow{3}{*}{$\begin{array}{l}\text { Student interaction } \\
\text { with a physical } \\
\text { medium (CD, DVD, } \\
\text { international TV, } \\
\text { website ...) }\end{array}$} & Pearson correlation & -0.071 & 10.000 & $0.585^{* *}$ & 0.039 \\
\hline & Sig. (2-tailed) & 0.510 & & 0.000 & 0.715 \\
\hline & $\mathrm{N}$ & 89 & 89 & 89 & 89 \\
\hline
\end{tabular}


(Table 10 continued)

\begin{tabular}{|c|c|c|c|c|c|}
\hline \multicolumn{6}{|l|}{ Correlation } \\
\hline & & $\begin{array}{l}\text { Are you } \\
\text { working } \\
\text { currently? }\end{array}$ & $\begin{array}{l}\text { Student } \\
\text { interaction with a } \\
\text { physical medium } \\
\text { (CD, DVD, } \\
\text { international TV, } \\
\text { website ...) }\end{array}$ & $\begin{array}{l}\text { Lecture by } \\
\text { professor } \\
\text { involving all } \\
\text { students }\end{array}$ & $\begin{array}{l}\text { Meeting outside of class among } \\
\text { more than two students }\end{array}$ \\
\hline \multirow{3}{*}{$\begin{array}{l}\text { Lecture by } \\
\text { professor } \\
\text { involving all } \\
\text { students }\end{array}$} & $\begin{array}{l}\text { Pearson } \\
\text { correlation }\end{array}$ & $0.393^{* *}$ & $0.585^{* * *}$ & 10.000 & $0.242^{*}$ \\
\hline & Sig. (2-tailed) & 0.000 & 0.000 & & 0.022 \\
\hline & $\mathrm{N}$ & 89 & 89 & 89 & 89 \\
\hline \multirow{3}{*}{$\begin{array}{l}\text { Meeting outside } \\
\text { of class among } \\
\text { more than two } \\
\text { students }\end{array}$} & $\begin{array}{l}\text { Pearson } \\
\text { correlation }\end{array}$ & $0.508^{* *}$ & 0.039 & $0.242^{*}$ & 10.000 \\
\hline & Sig. (2-tailed) & 0.000 & 0.715 & 0.022 & \\
\hline & $\mathrm{N}$ & 89 & 89 & 89 & 89 \\
\hline
\end{tabular}

Notes. " Correlation is significant at the 0.05 level (2-tailed). ${ }^{* 2}$ Correlation is significant at the 0.01 level (2-tailed). Source: The authors' elaboration.

\section{Conclusions}

Summing up the results of this investigation, it appears that nowadays the students of the "Marketing Research" subject at the University Rey Juan Carlos and as well the students of the following courses "Principles of Business Financial Management”, "Financial Management”, “Accounting”, and "Finance” at the Complutense University (all the students of the bilingual degrees) prefer collective bilingualism, that is, the educational techniques where are participating more than two students. In particular, the technique which is most valuated by students is the meeting with native speakers in a bar, cafeteria, etc. Some people might consider that students prefer this technique, because it is influenced by the fact that they are in an environment of leisure and relaxation. But it should be mentioned, that these techniques are less valued by students, when they have to meet outside the classroom, in this case usually they communicate only in Spanish and they bypass the English language.

Therefore, being with the English native speakers, students are forced to use English as a vehicular language. Also, the teacher's lecture is highly considered as valuable learning system in bilingualism. Therefore, from a strictly formal point of view, this technique is and will be the supreme technique of the university education. In any case, the bilingual teaching method is so extensive that can not be considered as an object of teaching - based on alternative techniques, but rather complementary technique. In other words, as final colophon: bilingualism is not individual or collective, but it is individual and collective bilingualism.

\section{References}

Bloomfield, L. (1933). Language. Nueva York: Holt.

Cummins, J. (2002). Lenguaje, Poder y Pedagogía: Niños y Niñas Bilingües Entre Dos Fuegos. Madrid: Morata.

García, E. (2005). Teaching and learning in two languages: Bilingualism and schooling in the United States. Nueva York: Teachers College Press.

Genesee, F. (Ed.) (1999). Program alternatives for linguistically diverse students. Santa Cruz, C.A.: Center for Research on Education, Diversity \& Excellence.

Haugen, E. (1953). The Norwegian language in America: A study in bilingual behavior. Filadelfia: University of Pennsylvania Press. 
Kotler, P., \& Lane, K. (2006). Dirección de marketing (12th ed.). Madrid: Pearson Educación.

Malhotra, N. K. (2004). Investigación de mercados un enfoque aplicado (4th ed.). México, D.F.: Pearson Educación.

Moreno, F. (2008). Principios de Sociolingüistica y Sociología del Lenguaje. Barcelona, Editorial Ariel.

Siguan, M., \& Mackey, W. F. (1986). Éducation et Bilinguisme. París: UNESCO.

Weinreich, U. (1952). Languages in contact. Mouton: La Haya. 